\title{
PENINGKATAN KEINOVATIFAN MELALUI PENGEMBANGAN KEPEMIMPINAN TRANSFORMASIONAL DAN EFIKASI DIRI
}

\author{
Sendy Sunardi ${ }^{1}$, Widodo Sunaryo ${ }^{2}$, Griet Helena Laihad ${ }^{2}$ \\ ${ }^{1}$ Guru SD Negeri Jogjogan 01 Cisarua, Kabupaten Bogor \\ ${ }^{2}$ Program Pascasarjana Universitas Pakuan \\ Email:pasca@unpak.ac.id
}

\begin{abstract}
The objective of this study is to find out how teacher's innovations can be improved, through researching and seeking relationships on: 1) transformational leadership of the principal teacher's innovations 2) self-efficacy with teacher's innovations 3) transformational leadership and self-efficacy together with teacher's innovations. This research was conducted on 163 samples of PNS teachers of Elementary School in Cisarua chosen proportionally by using proportional random sampling technique spread in 30 schools in Cisarua at Bogor district with degree of research significance equal to 0,05. This research was conducted using quantitative method by correlation technique. The conclusions are 1) There is a positive relationship with the low level of relationship on the transformational leadership $\left(X_{1}\right)$ with teacher's innovations $(Y)$ with the correlation coefficient $\left(r y_{1}\right)$ of 0.311 and regression equation $\left.\hat{Y}=101,740+0,295 X_{1} .2\right)$ There is a positive relationship with low level of relationship in self efficacy $\left(X_{2}\right)$ with teacher's innovations $(Y)$ with correlation coefficient (ry $)_{2}$ of 0.221 and regression equation $\left.\hat{Y}=107,109+0,261 X_{2}, 3\right)$ There is a positive relationship with level the low relation on transformational leadership $\left(X_{1}\right)$ and self-efficacy $\left(X_{2}\right)$ together with teacher's innovations $(Y)$ with correlation coefficient $\left(r y_{12}\right)$ of 0.346 and regression equation $\hat{Y}$ $=79,929+0,260 X_{1}+0,183 X_{2}$.
\end{abstract}

Keywords: Transformational Leadership, Self-Efficacy, Teacher's Innovations

\begin{abstract}
ABSTRAK
Guru dituntut untuk berinovasi. Penelitian ini bertujuan untuk mengetahui bagaimana inovasi guru dapat ditingkatkan melalui pencarian hubungan kepemimpinan transformasional dengan inovasi, hubungan self-efficacy dengan inovasi guru dan hubungan kepemimpinan transformasional dan self-efficacy bersama dengan inovasi guru. Penelitian ini dilakukan pada 163 sampel guru PNS Sekolah Dasar di Cisarua yang dipilih secara proporsional dengan menggunakan teknik proporsional random sampling yang tersebar di 30 sekolah di Cisarua di Kabupaten Bogor dengan tingkat signifikansi penelitian sebesar 0,05. Penelitian ini dilakukan dengan menggunakan metode kuantitatif dengan teknik korelasi. Temuan penelitian ini, yaitu: (1) Terdapat hubungan positif dengan tingkat hubungan yang rendah pada kepemimpinan transformasional (X1) dengan inovasi guru (Y) dengan koefisien korelasi (ry1) sebesar 0,311 dan persamaan regresi $\hat{Y}=101,740+0,295 X 1$; (2) Terdapat hubungan positif dengan tingkat hubungan rendah dalam self-efficacy (X2) dengan inovasi guru $(\mathrm{Y})$ dengan koefisien korelasi (ry2) sebesar 0,221 dan persamaan regresi $\hat{Y}=107,109+0,261 X 2$; dan (3) Terdapat hubungan positif dengan tingkat hubungan rendah pada kepemimpinan transformasional (X1) dan selfefficacy (X2) bersama dengan inovasi guru (Y) dengan koefisien korelasi (ry12) sebesar 0,346 dan persamaan regresi $\hat{Y}=79,929+0,260 X 1+0,183 X 2$.
\end{abstract}

Kata kunci: Kepemimpinan Transformasional, Efikasi Diri, Inovasi Guru 


\section{PENDAHULUAN}

Pendidikan menjadi sangat penting bagi setiap negara, karena pendidikan merupakan suatu proses yang dapat menghasilkan perubahan, perkembangan, kemampuan seseorang dalam membuktikan rasa percaya diri serta sikap dan perilaku yang inovatif. Pendidikan diselenggarakan berdasarkan rencana yang matang, mantap, jelas, lengkap dan menyeluruh dengan mempersiapkan peserta didik untuk tujuan kehidupan yang nyata melalui bimbingan pengajaran dan latihan sehingga mampu melaksanakan peranan-peranan untuk masa datang.

Perkembangan teknologi dan informasi yang cepat dalam berbagai aspek kehidupan termasuk dalam bidang pendidikan, merupakan suatu upaya untuk menjembatani masa sekarang dan masa yang akan datang dengan jalan memperkenalkan pembaharuanpembaharuan yang cenderung mengejar efisensi dan efektivitas. Pembaharuan mengiringi perputaran zaman yang tak henti-hentinya berputar sesuai dengan kurun waktu yang telah ditentukan. Kebutuhan akan layanan individual terhadap peserta didik dan perbaikan kesempatan belajar bagi mereka, telah menjadi pendorong utama timbulnya pembaharuan pendidikan. Oleh karena itu, lembaga pendidikan harus mampu mengantisipasi perkembangan tersebut dengan terus menerus mengupayakan suatu program yang sesuai dengan perkembangan anak, perkembangan zaman, situasi, kondisi, dan kebutuhan peserta didik.

\section{Keinovatifan}

Greenberg and Baron (2008: 568-572) mengemukakan bahwa inovasi adalah tindakan (proses) melakukan perubahan dari sesuatu yang telah terbentuk menjadi sesuatu yang baru. Inovasi menurut Schermerhorn (2005: 466-467) adalah tindakan memproses suatu ide baru untuk diwujudkan menjadi sesuatu yang memiliki kegunaan praktis. Inovasi terbagi dalam dua dimensi yakni, inovasi produk (barang, produk atau jasa yang baru) dan inovasi proses (prosedur atau cara kerja yang baru). Sedangkan menurut Stephen P. Robbins (2003: 571-572) Innovation is a new idea applied to initiating or improving product, process, and service. And dividing innovation into three dimensions of product innovation, from small improvement to change the product, process innovation, such as introduce new idea of doing the jobs, and services innovation, concerning all activities to improve the customer relationship and satisfaction.

Schermerhorn, Osborn, Hunt, Uhl-Bien (2005: 360-363) mendefinisikan bahwa inovasi adalah proses menciptakan gagasan baru dan mempraktikkannya. Ada dua dimensi yang mempengaruhi inovasi yaitu inovasi produk mengenalkan barang atau jasa baru untuk lebih memenuhi kebutuhan pelangga dan inovasi proses mengenalkan ke dalam operasi cara baru dan lebih baik dalam melakukan sesuatu.

Berdasarkan kajian teori diatas maka dapat disimpulkan bahwa keinovatifan guru adalah tindakan memproses dan mengimplementasikan sesuatu yang baru baik berupa ide-ide, produk atau layanan untuk mewujudkan suatu perubahan dalam kegiatan pembelajaran yang berkualitas.

\section{Kepemimpinan Transformasional}

Robbins dan Judge (2015: 261-263) berpendapat bahwa kepemimpinan trasnformasional adalah para pemimpin yang menginspirasi para pengikutnya untuk melampaui kepentingan diri sendiri dan yang berkemampuan untuk memiliki pegaruh secara mendalam dan luar biasa terhadap para pengikutnya. Colquitt, LePine, and Wesson (2009:448) mengemukakan bahwa kepemimpinan transformasional adalah kepemimpinan yang melibatkan inspirasi seluruh anggotanya untuk berkomitmen dalam rangka menuju visi bersama yang memberikan makna terhadap pengembangan potensi mereka sendiri dan beberapa permasalahan dari perspektif 
baru.

Kinicki dan Williams (2008: 44) mendefinisikan bahwa kepemimpinan transformasional adalah kepemimpinan yang mengubah karyawan untuk mengejar tujuan organisasi melebihi kepentingan pribadi. Bass dan Riggio (2006: 6) berpendapat bahwa kepemimpinan transformasional pemimpin yang menginspirasi para pengikutnya untuk mencapai hasil yang luar biasa dan dalam proses mengembangkan kapasitas kepemimpinan mereka sendiri.

Berdasarkan beberapa teori yang telah dikemukakan di atas dapat disimpulkan bahwa kepemimpinan transformasional adalah perilaku pemimpin kharismatik yang senantiasa menginspirasi para bawahannya sehingga mampu untuk mengembangkan potensi dan minat mereka sendiri dengan menjunjung tinggi nilai moral dan memiliki pandangan jauh ke depan untuk berkomitmen dalam rangka menuju visi bersama.

\section{Efikasi Diri}

Fred Luthans (2011: 203-206) menyatakan bahwa efikasi diri ditujukan pada tugas-tugas tertentu dan terbuka untuk pelatihan dan pengembangan. Colquitt, Lepine, Wesson (2009: 170172) mengemukakan bahwa efikasi diri didefinisikan sebagai keyakinan bahwa seseorang memiliki kemampuan yang dibutuhkan untuk menjalankan perilaku yang dibutuhkan untuk kesuksesan tugas.

Kreitner, A. Kinicki (2008: 127-129) efikasi diri adalah percaya pada kemampuan seseorang untuk melakukan suatu tugas. Fred Luthans (2011: 203-206) menyatakan bahwa efikasi diri ditujukan pada tugas-tugas tertentu dan terbuka untuk pelatihan dan pengembangan. Robbins. Timothy A. Judge (2015: 261-263) mengatakan bahwa efikasi diri adalaah suatu keyakinan individu bahwa dia mampu untuk melaksanakan tugas, dan membaginya ke dalam faktor kemahiran dalam melaksanakan, yaitu memperoleh pengalaman yang relevan dengan tugas atau pekerjaan, jika individu mampu melaksanakan pekerjaan dengan berhasil pada masa yang lalu, maka individu lebih percaya diri untuk melakukannya pada masa yang akan datang.

Berdasarkan teori diatas dapat disimpulkan bahwa efikasi diri adalah keyakinan diri seseorang akan potensinya dalam menghadapi suatu tantangan atau tugas tertentu.

\section{METODE PENELITIAN}

Penelitian ini menggunakan metode kuantitatif dengan model Survey korelasi. Variabel bebas dalam penelitian ini yaitu kepemimpinan transformasioanl $\left(\mathrm{X}_{1}\right)$ dan efikasi diri $\left(\mathrm{X}_{2}\right)$, sedangkan variabel terikat (Y) adalah keinovatifan guru. Populasi dalam penelitian ini yaitu Guru PNS SDN Kecamatan Cisarua Kabupaten Bogor. Sampel dalam penelitian ini ditentukan sebanyak 116 dengan menggunakan rumus Slovin. Pengambilan sampel pada masing-masing sekolah dilaksanakan dengan teknik proportional random sampling.

Data hasil penelitian kuantitatif dianalisis menggunakan statistik deskriptif dan statistik inferensial. Statistik inferensial yang menggunakan analisis regresi-korelasi. Analisis data dilakukan dengan langkah uji normalitas galat taksiran, uji homogenitas varians. Penetapan persamaan regresi, uji signifikansi persamaan regresi, linieritas regresi serta pengujian hipotesis dengan uji korelasi. Proses analisis data kualitatif dilakukan dalam dua tahap yaitu analisis selama proses pengumpulan data di lapangan dan analisis setelah pengumpulan data dengan cara membandingkan nilai data setiap butir menggunakan metode SITOREM 


\section{HASIL PENELITIAN \\ Pengujian Persyaratan Analisis}

\section{Uji Normalitas}

Hasil perhitungan uji normalitas galat taksiran $\left(\mathrm{Y}-\hat{\mathrm{Y}}_{1}\right)$ variabel keinovatifan guru atas variabel kepemimpinan transformasional diperoleh nilai $L_{\text {hitung }}$ sebesar 0,0948 sementara $L_{\text {tabel }}$ sebesar 0,0955. Persyaratan normal adalah $\mathrm{L}_{\text {hitung }}<\mathrm{L}_{\text {tabel }}$ dengan demikian galat baku taksiran $\left(\mathrm{Y}-\hat{Y}_{1}\right)$ variabel keinovatifan guru atas variabel kepemimpinan transformasional berdistribusi normal.

Hasil perhitungan uji normalitas galat taksiran $\left(\mathrm{Y}-\hat{\mathrm{Y}}_{2}\right)$ variabel keinovatifan guru atas variabel efikasi diri diperoleh nilai $L_{\text {hitung }}$ sebesar 0,0949 sementara $L_{\text {tabel }}$ sebesar 0,0955. Persyaratan normal adalah $\mathrm{L}_{\text {hitung }}<\mathrm{L}_{\text {tabel }}$ dengan demikian galat baku taksiran $\left(\mathrm{Y}-\hat{\mathrm{Y}}_{2}\right)$ variabel keinovatifan guru atas variabel efikasi diri berdistribusi normal.

\section{Uji Homogenitas}

Pengujian homogenitas dilakukan dengan menggunakan uji Bartlett. Berdasarkan hasil pengujian diperoleh nilai $\chi^{2}$ hitung $=39,25$ sedangkan $\chi^{2}$ tabel $=53,38$. Persyaratan data tersebut homogen jika $\chi^{2}$ hitung $<\chi^{2}$ tabel. Dengan demikian kelompok skor data keinovatifan guru (Y) atas kepemimpinan transformasional $\left(\mathrm{X}_{1}\right)$ berasal dari populasi yang homogen $\left(\chi^{2}\right.$ hitung $=$ $39,25<53,38=\chi^{2}$ tabel)

Pengujian homogenitas dilakukan dengan menggunakan uji Bartlett. Berdasarkan hasil pengujian diperoleh nilai $\chi^{2}$ hitung $=30,24$ sedangkan $\chi^{2}$ tabel $=44,98$. Persyaratan data tersebut homogen jika $\chi^{2}$ hitung $<\chi^{2}$ tabel. Dengan demikian kelompok skor data keinovatifan guru (Y) atas efikasi diri $\left(\mathrm{X}_{2}\right)$ berasal dari populasi yang homogen $\left(\chi^{2}\right.$ hitung $=30,24<44,98=\chi^{2}$ tabel $)$

\section{Pengujian Hipotesis}

\section{Hubungan antara Variabel Kepemimpinan Transformasional $\left(\mathrm{X}_{1}\right)$ dengan Keinovatifan Guru (Y)}

Berdasarkan hasil perhitungan nilai koefisien korelasi menunjukkan bahwa variabel kepemimpinan transformasional $\left(\mathrm{X}_{1}\right)$ dengan keinovatifan guru $(\mathrm{Y})$ menghasilkan nilai koefisien korelasi ( $\mathrm{ry}_{1}$ ) sebesar 0,311. Dari hasil uji signifikan diperoleh nilai $\mathrm{t}_{\text {hitung }}=3,499$ dengan nilai $t_{\text {tabel }(0,05: 114)}=1,981$ dan $t_{\text {tabel }(0,01: 114)} 2,619$. Hasil tersebut terlihat bahwa $t_{\text {hitung }}>$ $t_{\text {tabel. }}$ Dengan demikian, dapat disimpulkan bahwa terdapat hubungan positif yang sangat signifikan antara kepemimpinan transformasional $\left(\mathrm{X}_{1}\right)$ dengan keinovatifan guru $(\mathrm{Y})$.

Dengan mengetahui bahwa koefisien korelasi yang sangat signifikan, selanjutnya dapat ditentukan kontribusi kepemimpinan transformasioanl $\left(\mathrm{X}_{1}\right)$ terhadap keinovatifan guru $(\mathrm{Y})$ yang ditunjukkan melalui nilai koefisien determintasi $\left(\mathrm{r}^{2} \mathrm{y}_{1}\right)$ sebesar 0,097. Hal tersebut menunjukkan bahwa $9,7 \%$ keinovatifan guru dapat diterangkan oleh kepemimpinan transformasional. Adapun sisanya 90,3\% berhubungan dengan variabel lain.

\section{Hubungan antara Efikasi Diri $\left(\mathrm{X}_{2}\right)$ dengan Keinovatifan Guru (Y)}

Berdasarkan hasil perhitungan nilai koefisien korelasi menunjukkan bahwa variabel efikasi diri $\left(\mathrm{X}_{2}\right)$ dengan keinovatifan guru $(\mathrm{Y})$ menghasilkan nilai koefisien korelasi $\left(\mathrm{ry}_{2}\right)$ sebesar 0,221. Dari hasil uji signifikan diperoleh nilai $t_{\text {hitung }}=2,418$ dengan nilai $t_{\text {tabel }(0,05: 114)}=$ 1,981 dan $t_{\text {tabel }(0,01: 114)}=2,619$. Hasil tersebut terlihat bahwa $t_{\text {hitung }}>t_{\text {tabel }}$. Dengan demikian, dapat disimpulkan bahwa terdapat hubungan positif yang signifikan antara efikasi diri $\left(\mathrm{X}_{2}\right)$ dengan keinovatifan guru (Y).

Dengan mengetahui bahwa koefisien korelasi yang signifikan, selanjutnya dapat ditentukan kontribusi efikasi diri $\left(\mathrm{X}_{2}\right)$ terhadap keinovatifan guru $(\mathrm{Y})$ yang ditunjukkan melalui nilai koefisien determintasi $\left(\mathrm{r}^{2} \mathrm{y}_{2}\right)$ sebesar 0,049 . Hal tersebut menunjukkan bahwa 4,9\% 
keinovatifan guru dapat diterangkan oleh efikasi diri. Adapun sisanya 95,1\% berhubungan dengan variabel lain.

\section{Hubungan antara Kepemimpinan Transformasional $\left(X_{1}\right)$ dan Efikasi Diri $\left(X_{2}\right)$ secara bersama-sama dengan Keinovatifan Guru (Y)}

Hasil perhitungan nilai koefisien korelasi ganda (ry 12) sebesar 0,346. Dari hasil uji signifikan diperoleh nilai $t_{\text {hitung }}=7,685$ dengan nilai $t_{\text {tabel }(0,05: 114)}=1,981$ dan $t_{\text {tabel }(0,01: 114)}=2,619$. Hasil tersebut terlihat bahwa $t_{\text {hitung }}>t_{\text {tabel. }}$. Dengan demikian, dapat disimpulkan bahwa terdapat hubungan positif yang sangat signifikan antara kepemimpinan transformasional $\left(\mathrm{X}_{1}\right)$ dan efikasi diri $\left(\mathrm{X}_{2}\right)$ secara bersama-sama dengan keinovatifan guru $(\mathrm{Y})$.

Dengan mengetahui bahwa koefisien korelasi yang sangat signifikan, selanjutnya dapat ditentukan kontribusi kepemimpinan transformasional $\left(\mathrm{X}_{1}\right)$ dan efikasi diri $\left(\mathrm{X}_{2}\right)$ secara bersama-sama terhadap keinovatifan guru (Y) yang ditunjukkan melalui nilai koefisien determintasi $\left(\mathrm{r}^{2} \mathrm{y}_{12}\right)$ sebesar 0,120 . Hal tersebut menunjukkan bahwa $12 \%$ keinovatifan guru dapat diterangkan oleh kontribusi kepemimpinan transformasional dan efikasi diri secara bersama-sama. Adapun sisanya $88 \%$ berhubungan dengan variabel lain.

\section{Uji korelasi parsial}

Berdasarkan hasil perhitungan uji korelasi parsial yang pertama diperoleh nilai korelasi parsial antara kepemimpinan transformasional $\left(\mathrm{X}_{1}\right)$ dengan keinovatifan guru $(\mathrm{Y})$ dimana efikasi diri $\left(\mathrm{X}_{2}\right)$ dikontrol $\left(\mathrm{ry}_{12}\right)=0,273$. Berdasarkan hasil uji signifikansi, nilai tersebut sangat signifikansi $\left(F_{h}=3,499>F_{t}=2,619_{(\alpha=0,01)}\right)$. Dengan demikian dapat disimpulkan bahwa hubungan antara kepemimpinan transformasional dengan keinovatifan guru tidak dipengaruhi variabel efikasi diri.

Hasil perhitungan uji korelasi parsial yang kedua diperoleh nilai korelasi parsial antara efikasi diri $\left(\mathrm{X}_{2}\right)$ dengan keinovatifan guru $(\mathrm{Y})$ dimana kepemimpinan transformasional $\left(\mathrm{X}_{1}\right)$ dikontrol $\left(\right.$ ry $\left._{21}\right)=0,159$. Berdasarkan hasil uji signifikansi, nilai tersebut signifikansi $\left(\mathrm{F}_{\mathrm{h}}=\right.$ $\left.2,418>\mathrm{Ft}=2,619_{(\alpha=0,01)}\right)$. Dengan demikian dapat disimpulkan bahwa hubungan positif antara efikasi diri dengan keinovatifan guru tidak dipengaruhi oleh variabel kepemimpinan transformasional.

\section{PEMBAHASAN}

\section{Hubungan antara kepemimpinan transformasional dengan keinovatifan guru}

Hasil penelitian yang menunjukkan terdapat hubungan antara kepemimpinan transformasional dengan keinovatifan guru dimaknai bahwa dalam suatu organisasi dimana kepemimpinan transformasional dipersepsikan baik oleh anggota organisasi maka keinovatifan guru tersebut akan tinggi. Kekuatan hubungan antara kepemimpinan transformasional dengan keinovatifan guru tercermin pada nilai koefisien korelasi sebesar 0,311. Keragaman pada keinovatifan guru yang terkait erat dengan kepemimpinan transformasional tercermin dari nilai koefisien determinasi (r2) sebesar 0,097 yang dimaknai 9,7\% keragaman pada keinovatifan guru dapat dijelaskan oleh kepemimpinan transformasional sedangkan 90,3\% sisanya dipengaruhi oleh faktor-faktor lain. Berdasarkan data hasil penelitian kuantitatif makan terdapat hubungan positif antara kepemimpinan transformasional dengan keinovatifan guru.

Hasil penelitian tersebut sejalan dengan Penelitian yang dilakukan oleh Imran dan M. Haque (2011: 35) yang berjudul "Mediating Effect of Organizational Climate between Transformational Leadership and Innovative Work Behavior" menyimpulkan bahwa terdapat 
hubungan yang signifikan antara kepemimpinan transformasional dengan inovasi yang ditunjukkan dengan koefisien korelasi $0,32(\rho<0,01)$.

Berdasarkan uraian di atas, maka kepemimpinan transformasional merupakan salah satu faktor penentu dalam meningkatkan keinovatifan guru.

\section{Hubungan antara efikasi diri dengan keinovatifan guru}

Hasil penelitian yang menunjukkan terdapat hubungan positif antara efikasi diri dengan keinovatifan guru dimaknai bahwa guru yang memiliki efikasi diri tinggi akan berdampak pada keinovatifan guru yang tinggi. Kekuatan hubungan antara efikasi diri dengan keinovatifan guru tercermin pada nilai koefisien korelasi sebesar 0,221. Keragaman pada keinovatifan guru yang terkait dengan efikasi diri tercermin pada nilai koefisien determinasi 0,120 atau $12 \%$, sedangkan $88 \%$ sisanya dipengaruhi oleh faktor-faktor lain.

Hasil penelitian tersebut sejalan dengan Penelitian yang dilakukan oleh Mikail Momeni, Habib Ebrahimpour, dan Mohammad Bashokoh Ajirloo (2014:26) tentang "The Effect of Employees 'Self-Efficacy on Innovative Work Behavior at School Security Organization Employees in Ardabil Province", menyimpulkan bahwa terdapat hubungan yang signifikan antara efikasi diri dengan inovasi yang ditunjukkan dengan koefisien korelasi 0,587 $(\rho<0,000)$.

Berdasarkan uraian di atas, maka efikasi diri merupakan salah satu faktor penentu dalam meningkatkan keinovatifan guru.

\section{Hubungan antara kepemimpinan transformasional dan efikasi diri dengan keinovatifan guru}

Hasil penelitian menunjukkan terdapat hubungan positif antara kepemimpinan transformasional dan efikasi diri dengan keinovatifan guru dimaknai bahwa kepala sekolah yang menunjukkan gaya kepemimpinan transformasional yang baik serta di sekolah tersebut memiliki efikasi diri guru yang baik maka keinovatifan guru akan baik. Dengan koefisien korelasi sebesar 0,346. Keragaman pada keinovatifan guru yang dapat dijelaskan akibat pengaruh kepemimpinan transformasional dan efikasi diri didapatkan dari nilai Koefisien determinasi sebesar 0,120 yang dimaknai bahwa $12 \%$ faktor keinovatifan guru ditentukan secara bersama-sama oleh kepemimpinan transformasional dan efikasi diri.

Berdasarkan uraian di atas, maka kepemimpinan transformasional dan efikasi diri merupakan salah satu faktor penentu dalam meningkatkan keinovatifan guru.

Selain itu untuk melihat seberapa besar kekuatan hubungan antara variabel bebas dan variabel terikat serta untuk mendapatkan solusi optimal dari penelitian ini serta untuk melakukan optimasi terhadap masing-masing indikator setiap variabel penelitian dilakukan dengan pemberian bobot pada masing-masing indikator, berdasarkan Teori Pengenalan Ilmiah untuk Riset Operasi di bidang Manajemen Pendidikan atau dikenal dengan SITOREM (Hardhienata, S:2017) seperti ditunjukkan pada gambar berikut : 


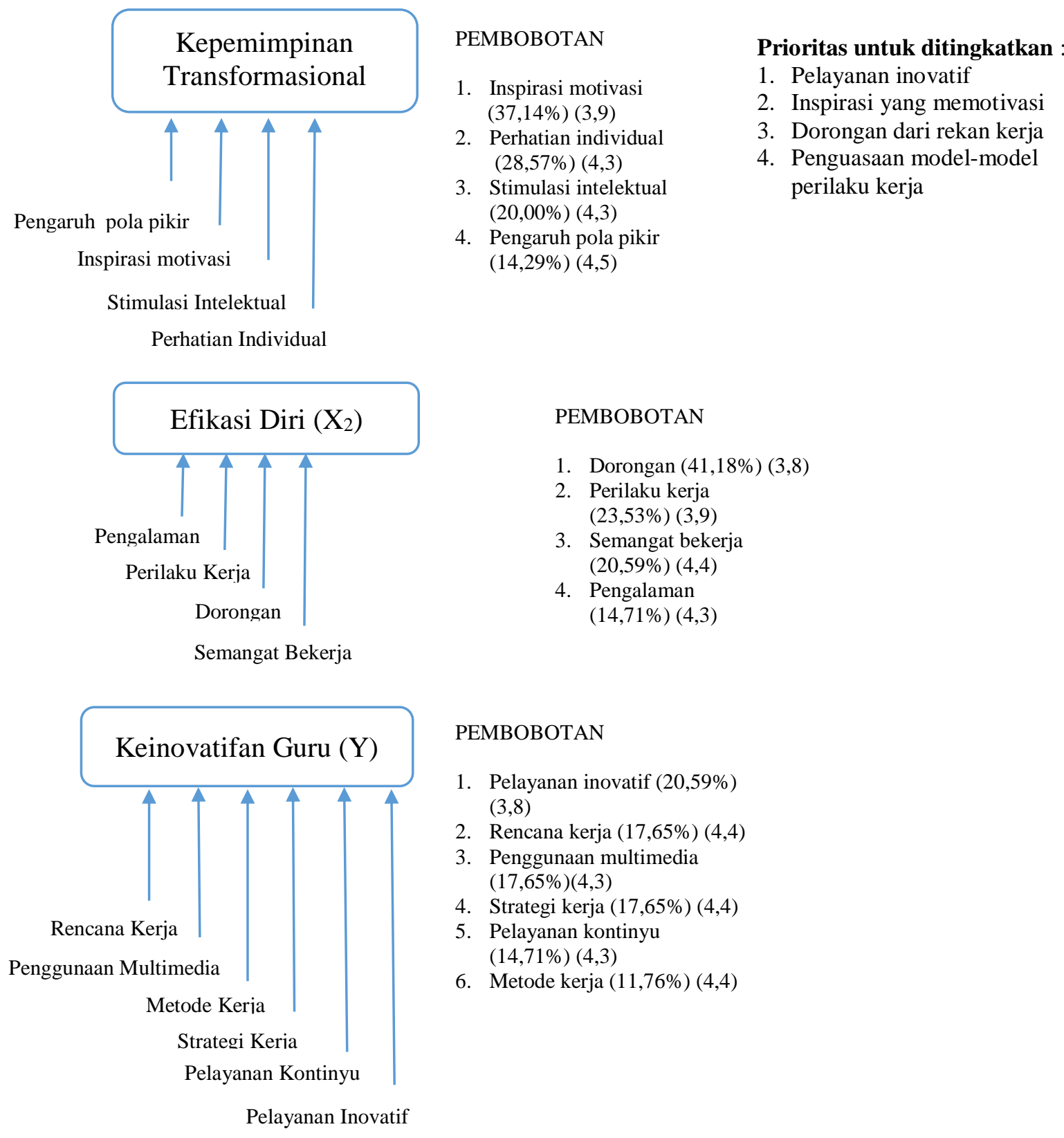

\section{SIMPULAN}

Hasil analisis membuktikan bahwa terdapat hubungan yang positif antara Kepemimpinan Transformasional dan Efikasi Diri baik sendiri-sindiri maupun secara bersama-sama dengan Keinovatifan Guru. Hal ini mencerminkan bahwa untuk meningkatkan Keinovatifan guru dapat dilakukan dengan cara meningkatkan Kepemimpinan Transformasional dan perbaikan Efikasi Diri.

\section{DAFTAR PUSTAKA}

Bass Bernard M. dan Ronald E. Riggio. Transformational Leadership. London: Lawrence Erlbaum Associates, Publishers , 2006

Colquitt J. A, J. A. Lepine, M. J. Wesson. Organizational Behavior. New York McGraw-Hill 2009 
Colquitt, J. A, J. Le Pine, and M. Wesson. Organizational Behavior. New York: McGraw-Hill, 2009

George, Jennifer M. and Gareth R. Jones. Understanding and Managing Organizational Behavior. Upper-Saddle River, NJ: Prentice-Hall. 2012

Gibson J. I, J.M. Ivancevich, J.H. Donnelly, Jr., and R. Konopaske. Organizations: Behavior, Structure and Processes. New York: McGraw-Hill, 2006.

Greenberg J. and R.A. Baron. Behavior in Organizations. Upper Saddle River, NJ: Pearson Prentice-Hall, 2008

Griffin Ricky W. Manajemen. Houghton Mifflin Company, Boston, USA. 2003

Kinicki Angelo \& Brian K. Williams. Management A Practical Introduction. New York: McGraw-Hill, 2008

Kreitner R., A. Kinicki. Organizational Behavior. McGraw-Hill New York. 2008

Luthans Fred. Organizational Behavior. McGraw-Hill New York. 2011

Robbins Stephen P. Organizational Behavior. New York: Prentice Hall, 2003

Robbins Stephen P., Timothy A. Judge, Organizational Behavior. Upper Saddle River, New Jersey. 2015

Schermerhorn John R., Jr. Management. New York: John Wiley \& Sons, Inc., 2005

Schermerhorn, Osborn, Hunt, Uhl-Bien. Organizational Behavior. New York: John Wiley \& Sons, Inc., 2005

Schemerhorn, Osborn, Uhl-Bien and Hunt, Organizational Behavior. 111 River Street, Hoboken, New Jersey. 2008 